\title{
PROFILE OF PROSPECTIVE TEACHERS' MATHEMATICAL COMMUNICATION ABILITY REVIEWED FROM ADVERSITY QUOTIENT
}

\author{
Muhtarom*, Adelia Dian Pratiwi, Yanuar Hery Murtianto \\ Universitas PGRI Semarang, Indonesia
}

\begin{tabular}{l} 
Article Info \\
\hline Article history: \\
Received Sep 14, 2020 \\
Revised Jan 15, 2021 \\
Accepted Jan 16, 2021 \\
\hline
\end{tabular}

\section{Keywords:}

Adversity Quotient, Mathematical Communication Ability

\begin{abstract}
Communication skills are an essential aspect that students need to possess by students who want to succeed in their studies, where students' mathematical communication can organize mathematical thinking both orally and in writing. While AQ is intelligent in facing difficulties, a student must face the problems that exist in them. This study aims to determine the profile of prospective mathematics prospective teacher's mathematical communication skills in terms of adversity quotient. This study was conducted on mathematics education students in the 6th semester of Universitas PGRI Semarang. This research is a descriptive qualitative study. Subjects taken from 57 respondents were three students in the category of climbers, campers, and quitters. Written tests and interviews do data collection. Indicators of mathematical communication skills used in this study include drawing, writing, and mathematical expression. The results showed that the subject climber can meet all the indicators of mathematical communication skills and can be said to be good. Subject campers tend to meet all indicators of mathematical communication skills, have the power of communication in indicators drawing, and be quite useful. Quitter's subject tends not to meet all the communication indicators. The subject does not answer the drawing indicator's problem, and the writing and mathematical expression indicators are still wrong.
\end{abstract}

Copyright $\odot 2021$ IKIP Siliwangi. All rights reserved.

\section{Corresponding Author:}

Muhtarom,

Department of Mathematics Education

Universitas PGRI Semarang,

J1. Sidodadi Timur No. 24, Dr. Cipto Semarang, Central Java 50232, Indonesia.

Email: muhtarom@upgris.ac.id

\section{How to Cite:}

Muhtarom, M., Pratiwi, A. D., \& Murtianto, Y. H. (2021). Profile of prospective teachers' mathematical communication ability reviewed from adversity quotient. Infinity, 10(1), 93-108.

\section{INTRODUCTION}

The 21st century is a century marked by the occurrence of a massive transformation from an agrarian society to an industrial society and continues to a knowledgeable society (Soh, Arsad, \& Osman, 2010). Life in the 21st century requires a variety of skills that must be mastered by someone, education is becoming increasingly important to ensure students have learning and innovation skills, skills to use technology and information media, and can work, and survive using life skills (Wijaya, Sudjimat, \& Nyoto, 2016). 
Scott (2015) states in the International Commission on Education for the Twentyfirst Century proposes four visions of learning, namely knowledge, understanding, competence for life, and competence to act. In addition to this vision, four principles known as the four pillars of education are formulated, namely learning to know, lerning to do, learning to be and learning to live together. Fridanianti, Purwati, and Murtianto (2018) state that strengthening character education in schools must be able to foster student character to be able to think critically, creatively, be able to communicate, and collaborate, who are able to compete in the 21 st century. This is in accordance with the four competencies that students must have in the 21 st century which is called $4 \mathrm{C}$, namely critical thinking and problem solving, creativity, communication skills, and the ability to work together.

Communication is one of the skills in Learning to do, oral and written communication skills contribute to career development in the 21 st century. The results of an analytical study conducted by Wardhani \& Rumiati (Salam, 2017), the cause of the low mathematics achievement of Indonesian students in the 2015 TIMSS results is due to the weakness of Indonesian students in working on questions that require several abilities, one of the abilities needed is the ability to communicate in mathematics. This can be caused by student confusion in presenting ideas or ideas in the form of symbols, graphs, tables or other media to clarify math problems. The results of the 2018 PISA assessment (Nugrahanto \& Zuchdi, 2019) show that the mathematical abilities of students in Indonesia are still low. One of the low mathematical abilities is mathematical communication skills, this can be caused by student confusion in presenting ideas or ideas in the form of symbols, graphs, tables or other media to clarify mathematical problems. Ulfa, Buchori, and Murtianto (2017) stated that in general the process of learning mathematics in the classroom is teacher-centered. This is in line with Hampson, Patton, and Shanks (2011) who state that high-quality teachers are those who have a strong influence on student achievement.

The ability to communicate in learning activities is said to be good if the ability of a teacher and lecturer to create a communicative climate, where between lecturers and students or teachers with students as subjects are actively involved in learning activities, both verbally and nonverbally, in other words this communicative climate as a vehicle for the implementation of learning in accordance with the design and achieving learning objectives (Son, 2015). It would be better if the provision of mathematical communication skills is integrated in every lecture. To realize good students' mathematical communication skills given by the teacher, trained or prepared since becoming prospective teacher. Son (2015) also adds, of course it is not effective and efficient if prospective mathematics teacher students only get a theory of mathematical communication in a subject without getting enough opportunities to practice it, it would be better if the provision of mathematical communication skills is integrated in every lecture. Hapsari, Nizaruddin, and Muhtarom (2019) state that teachers play a very important role in improving the quality of learning and learning outcomes that will be achieved by students before going to a higher level.

Many students still have imperfect mathematical communication skills. Paradesa and Ningsih (2017) states that the ability of students in the aspect of mathematical communication seen from the ability to provide mathematical evidence in the form of facts and data is still experiencing difficulties. If it is related to the problem of mathematical communication skills, the type of intelligence can be used, namely Adversity Quotient (AQ). AQ is often identified with fighting power against adversity. AQ is considered to be able to support student success in increasing achievement motivation (Hidayat \& Husnussalam, 2019; Hidayat, Noto, \& Sariningsih, 2019; Hidayat, Wahyudin, \& Prabawanto, 2018).

Many studies have been conducted to see the effect of AQ, including: Hidayat, Herdiman, Aripin, Yuliani, and Maya (2018) who try to improve AQ and student teacher student mathematical creative reasoning, stating that AQ has a positive influence on the 
development of students' mathematical creative reasoning abilities prospective teacher. Kartika and Yazidah (2019) also tried to analyze the ability of mathematical proof in real analysis courses based on AQ, stating that climbers' students are more able to compile direct evidence than quitters and campers students. Paramita (2017) also conducted research on mathematical communication skills in terms of AQ through the application of the SCSS learning model in students class VIII, showing that quitters tend not to be able to meet all indicators of mathematical communication skills, campers subject tends to be able to fulfill two indicators, namely the ability to state a situation to in mathematical language and the ability to visualize mathematical ideas, the climbers subject was able to fulfill all indicators. Yuniarti (2015) also conducted research on the analysis of the results of the diagnostic assessment of mathematical communication skills in Osborn learning based on AQ, and the results showed that the quitter category student subjects had not been able to fulfill almost every mathematical communication indicator, the camper category was quite capable in several indicators of mathematical communication, and the climber category.

Based on the above explanation that AQ has a significant effect in determining the success of students' mathematical communication skills, therefore the mathematical communication skills of students who have high AQ or students with climbers level will be different from the mathematical communication skills of students who have AQ at the campers and quitters level. Thus the purpose of this study is to determine and investigate in depth the AQ profile of prospective mathematics teacher students on mathematical communication skills.

\section{METHOD}

The method used in this research is descriptive qualitative research method using written and oral data. Because when the research was being carried out, it was during the Covid-19 pandemic, social distancing, and work from home, so this research was carried out online, where the AQ questionnaire was filled out via google form, and a written test of mathematical communication was carried out via the WhatsApp group video call, while interviews were conducted via Whatsapp call. The subjects defined in this study were 3 students at 6th semester of the Mathematics Education Study Program of the Universitas PGRI Semarang class of 2017 including one student with AQ quitters, one student with AQ campers, and one student with AQ climbers. This study used purposive sampling. Sugiyono (2008) states that purposive sampling is a technique of sampling data sources with certain considerations, with the consideration that the person we choose is considered to know best about what we expect, making it easier for researchers to explore the object or social situation under study.

The instruments used in this study included the AQ questionnaire, the mathematical communication skills test sheet, and the interview guide. The AQ questionnaire for sixth semester mathematics education students was given to two classes via google form and obtained 57 respondents. The AQ questionnaire instrument was adapted by Stoltz (2000) and has been validated by one counseling lecturer and three mathematics lecturers at the Universitas PGRI Semarang. This questionnaire was conducted to select 3 students with the categories quitters (MM), campers (KAL), and climbers (NDC). In this study, the climber subject was taken with the highest questionnaire score in the climbers category, the camper subject was taken with the middle questionnaire score in the campers' category, and the quitter subject was taken with the lowest questionnaire score in the quitters' category.

After determining each subject in the AQ category, then an online written test was carried out through the WhatsApp video call group for students who had the intelligence of quitters, campers, and climbers. The questions given consist of one story item on calculus 
material, which has been validated by three mathematics lecturers. Indicators of mathematical communication skills used include: 1) Writing, which is to provide answers using your own language or problems using writing and algebra, listening to, discussing and writing about mathematics, and being able to explain ideas or situations from a picture or graphic with words itself in writing; 2) Drawing, namely reflecting real objects, pictures, and diagrams into mathematical ideas and vice versa, and expressing a situation with pictures or graphs; 3) Mathematical expressions, namely expressing mathematical concepts by expressing everyday events in mathematical language or symbols, and expressing a situation in the form of a mathematical model. Before conducting the interview, the researcher checked back one by one the answers of each subject and checked the location of the truth and error in each indicator of mathematical communication.

Interviews were conducted online via WhatsApp calls to get more in-depth information about the mathematical communication forms possessed by these students. The interview instrument was validated by three mathematics lecturers. The interviews were conducted for approximately 10-20 minutes. To maintain the validity of the data in this study, triangulation was used. The triangulation used was method triangulation. After obtaining the results of the analysis of the written test answers and the interview data analysis, then a comparison is made to determine whether the data obtained is valid or not. And the result states that all data for climbers, campers, and quaitters subject can be said to be valid.

\section{RESULTS AND DISCUSSION}

\subsection{Results}

The first step was to determine the students as categories climbers, campers, and quitters. From the AQ questionnaire that has been distributed, it was obtained from 57 respondents that $3.51 \%$ of students with AQ quitters, $0 \%$ of students with AQ quitters to AQ campers, $31.58 \%$ of students with AQ campers, $57.89 \%$ of students with AQ campers to AQ climbers, and $7.02 \%$ of students with AQ climbers as in the following Figure 1.

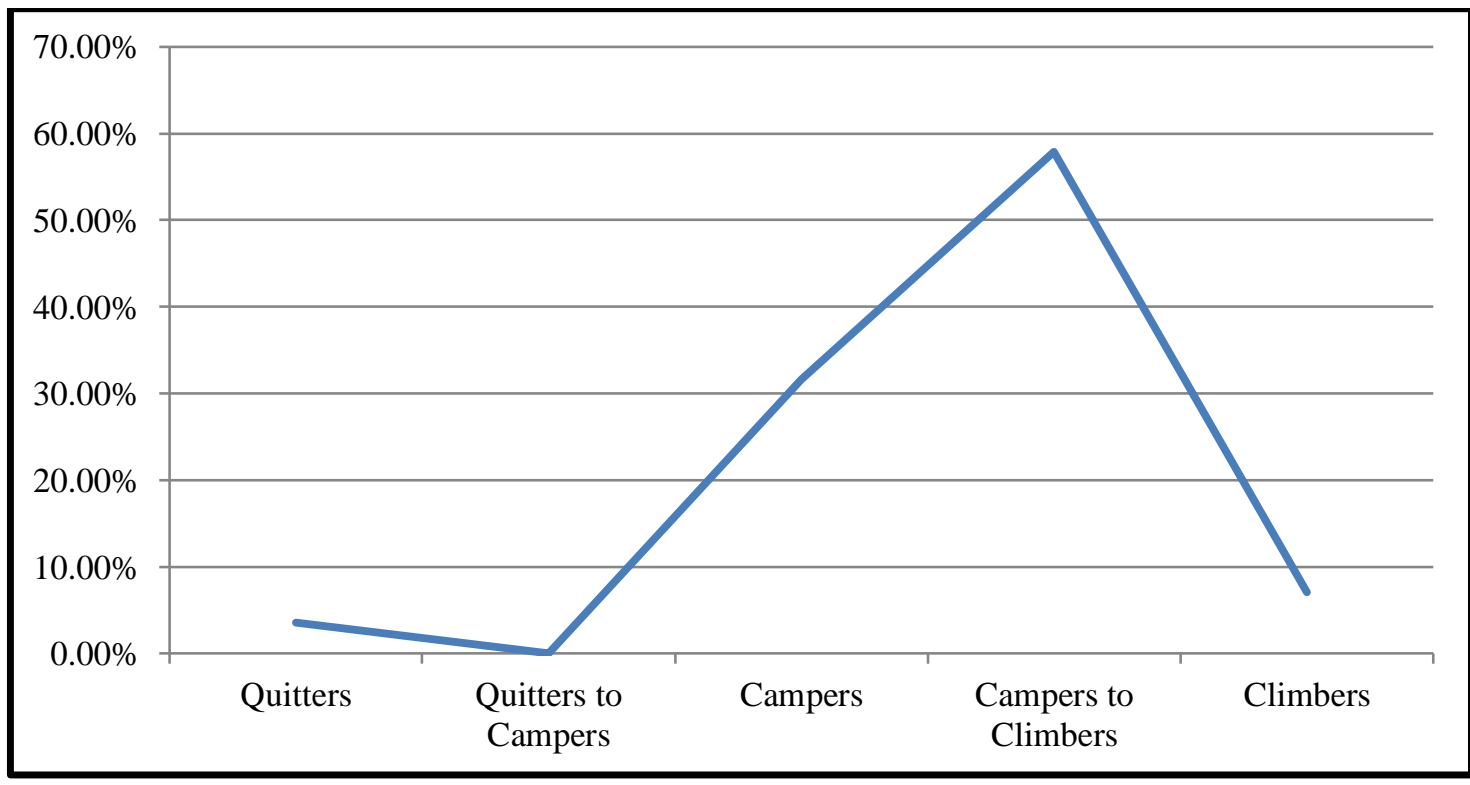

Figure 1. Graph of the number of students for each AQ 
After selecting 3 students with the categories climbers, campers, and quitters, then the three students were given questions on communication skills tests and interviews. Instruments used for mathematical communication skills include drawing, writing, and mathematical expression.

\subsubsection{NDC Subject}

The NDC subject fulfills following the indicators of mathematical communication drawing skills as shown in Figure 2. NDC subject can state the problem in the form of an image correctly and accurately and provide information on the length, width, and height of the problem in the question.

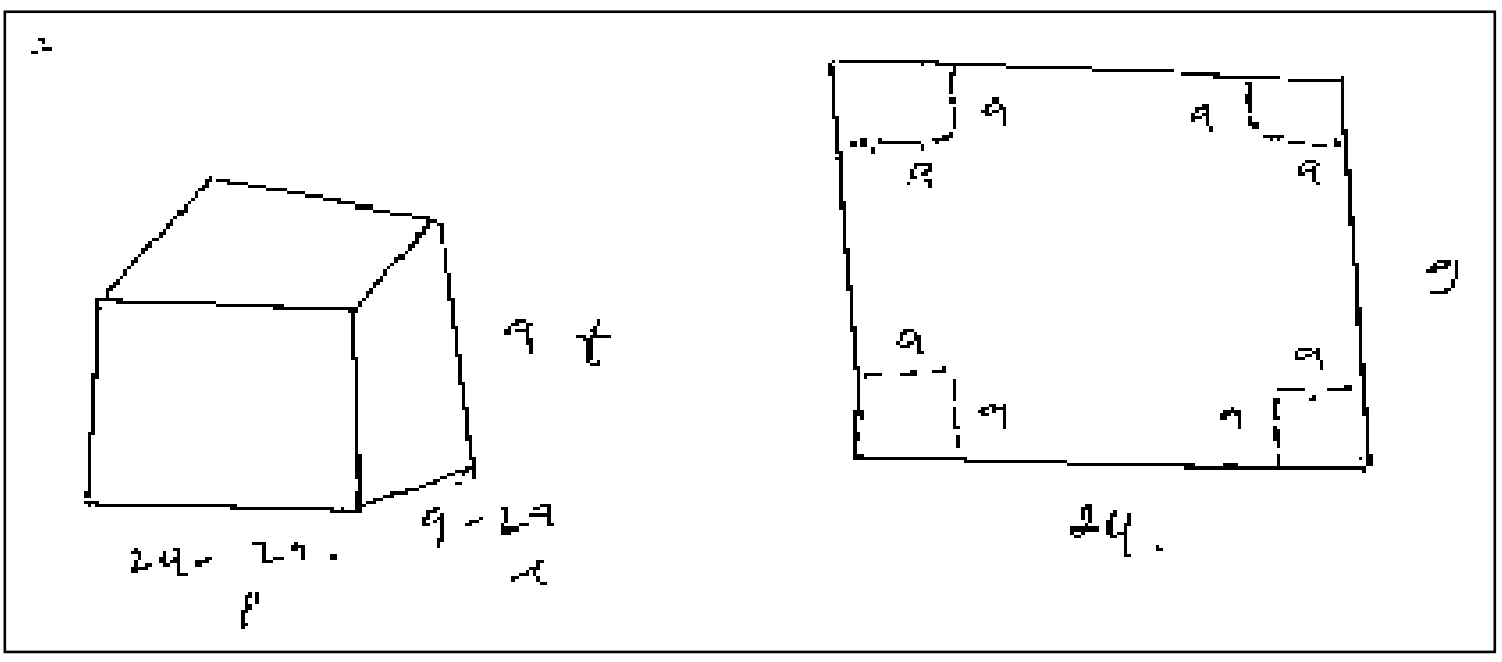

Figure 2. Answers to drawing the NDC subject

Based on the results of the interviews conducted, the NDC subject is able to meet the indicators of mathematical drawing communication skills and can smoothly explain problems into the form of images correctly and accurately and is able to smoothly explain the length, width, and height of the drawings he has made in his answer sheet. An excerpt from the interview with the NDC subject is presented as follows:

Researcher : What steps do you take?

NDC : This is what is asked for the maximum volume, so the first thing to do is to draw a square first, there are 4 edges, so all of them are cut, so it turns out to be a picture that is 24-2a in length, 9-2a in width and a height.

The NDC subject fulfills following the indicators of mathematical communication writing skills as shown in Figure 3. NDC subjects can use mathematical language appropriately and correctly, and are able to explain ideas or situations from images that have been made previously in their own words in writing. The subject takes his own side in written form, the subject considers the side of the square which is cut off with the symbol "a", and also write an explanation in determining the interval "a"correctly. 


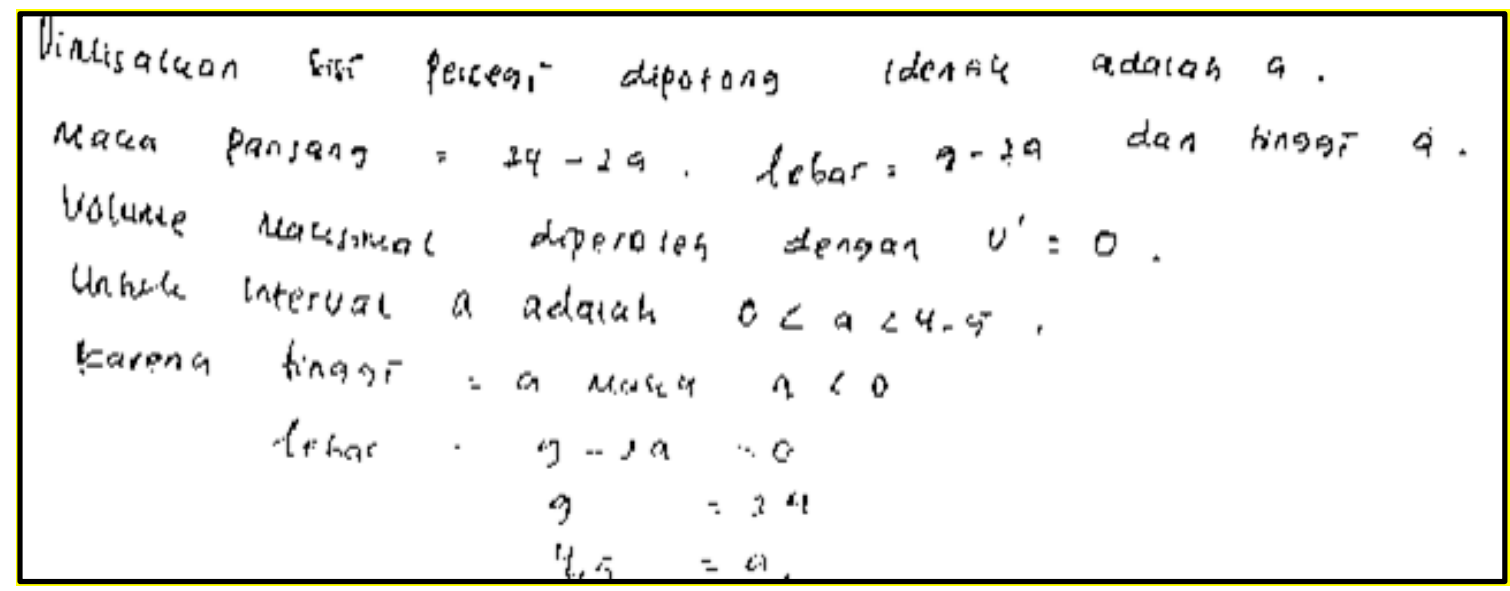

Figure 3. Answers to writing the NDC subject

Based on the results of the interviews conducted, the NDC subject is able to meet the indicators of writing mathematical communication skills and can explain fluently an idea or situation from a previously made image and can also explain the example of the square side used, and be able to state and explain how to determine the interval to meet the volume maximum sought. Here are excerpts of interviews with the subject NDC:

Researcher :Yes... Then after that?

NDC : So after that, suppose the square side is cut identically is " $a$ ", then the length is 24-2a, the width is 9-2a and the height is " $a$ ".

Researcher : Then how to determine the maximum volume how?

NDC : To determine the maximum volume with $V^{\prime \prime}=0$

Researcher : Yes... continue?

NDC : To determine the a interval it is $0<a<4.5$

Researcher : The reason?

NDC :You see, so there is a value, sis, the height is $a$, then the " $a$ " is less than 0.

Researcher : Where did you determine the 4.5 from?

NDC : That's from the width, the width is $9-2 a=0$, we move the segment so $9 / 2=a$, so $4.5=a$.

The NDC subject fulfills the following indicators of mathematical communication mathematical expression skills as shown in Figure 4. NDC subjects can state mathematical solutions in writing clearly and precisely, are able to use mathematical symbols and perform calculations or get complete and correct solutions. The subject is able to determine the length of the shape she has previously made with the values $24-2 \mathrm{a}$, and for the width $9-2 \mathrm{a}$, and the height a. Then the subject is able to write the volume formula used with $\mathrm{V}=$ p.l.t, the subject is also able to apply the first derived properties with $\mathrm{V}^{\prime}=0$ and is able to determine the value "a" that meets the maximum volume sought, and performs calculations correctly both in calculating the initial volume, determine the equation $V^{\prime}$, find the value of a, and determine the maximum volume. 


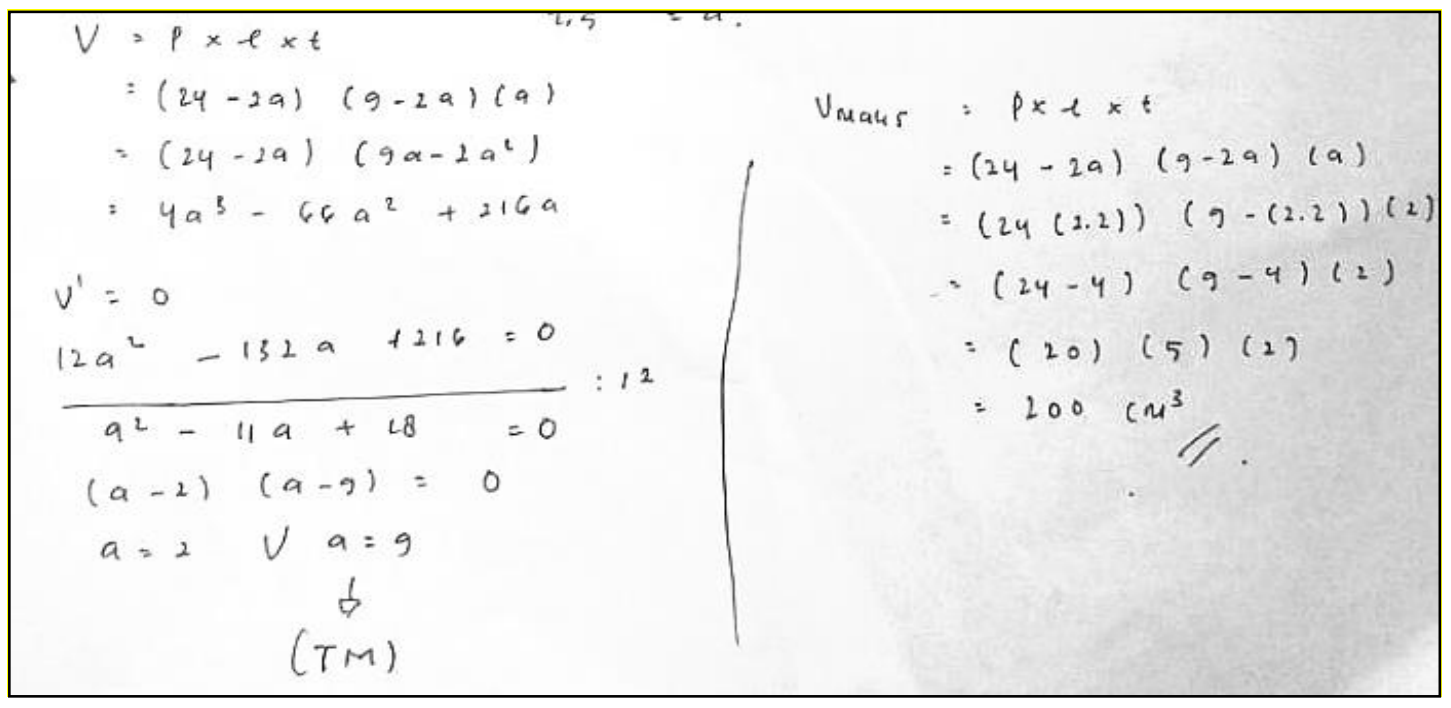

Figure 4. Answers to mathematical expression the NDC subject

Based on the results of the interviews conducted, the NDC subject is able to meet the indicators of mathematical expression and can explain mathematical solutions clearly and precisely, and is able to explain mathematical calculations and correct answers. An excerpt from the interview with the NDC subject is presented as follows:

Researcher: What do you do after that?

NDC : I determine the volume first, the volume formula is p.l.t, now enter the length is 24-2a, the width is 9-2a, the height is a, after that we operate the volume, the result is $4 a^{3}-66 a^{2}+216 a$.

Researcher: Then what is the next step?

NDC : So after that, determine the maximum volume with $V^{\prime}=0$, now determining $V^{\prime}=0$, we will derive it from the result of the volume which was $12 a^{2}$ $132 a+216=0$, so continue to divide by 12 , now the result is it is equal to 2 or a is equal to 9, now for $a=9$ it does not meet.

Researcher: Why not fulfill that for what reason?

NDC : Because the interval was less than 4.5.

Researcher: How do you continue to determine the maximum volume?

NDC : Now the maximum volume uses the formula, which is length times width times height, now we enter the one that is known to be 24-2a in length, 9-2a in width, the height is " $a$ ". That's what $V$ "= 0 has already been obtained which is equal to 2, continue to be added to the formula so the maximum volume is $200 \mathrm{~cm}^{3}$.

\subsubsection{KAL Subject}

The KAL subject fulfills the following indicators of mathematical communication drawing skills as shown in Figure 5. KAL subjects can state the problem in the form of an image correctly and precisely and are able to provide information on the length, width, and height of the problem in the question. 


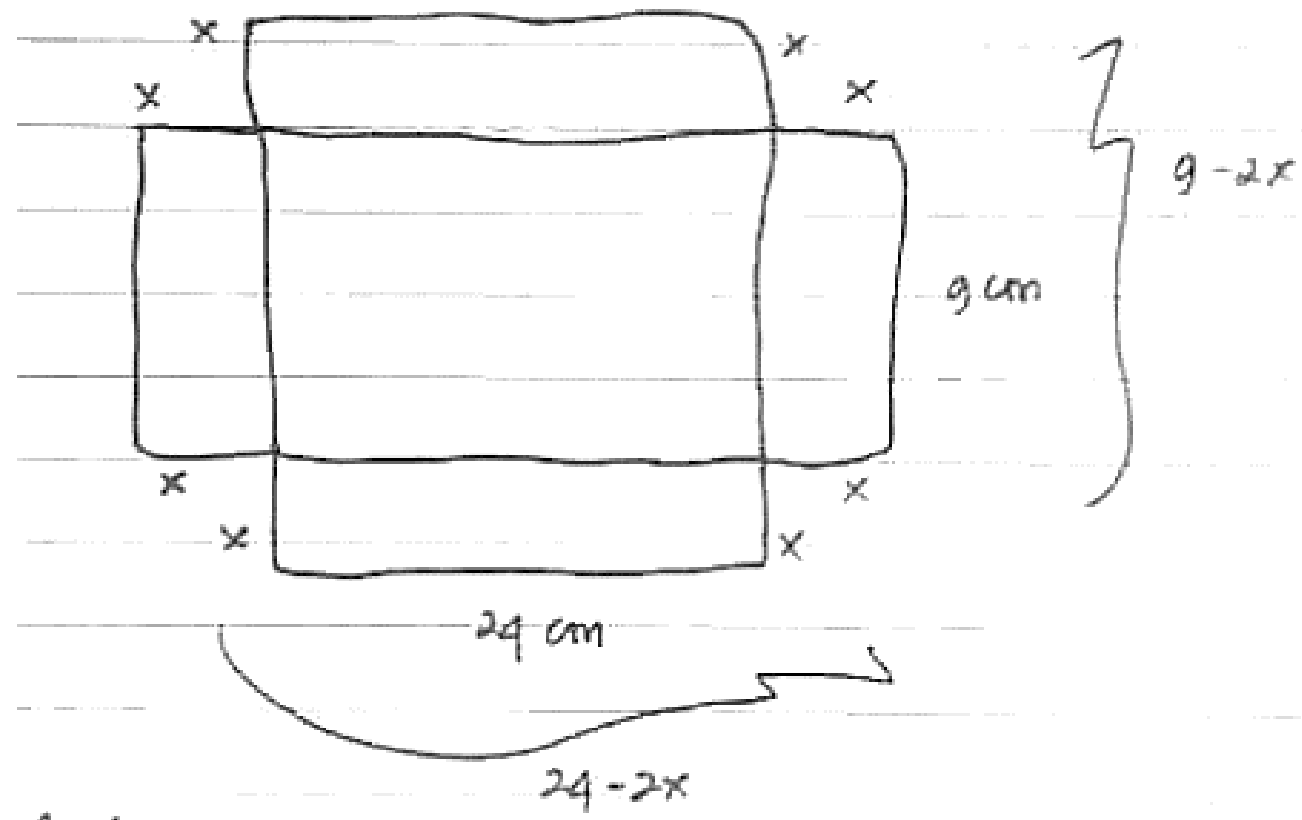

Figure 5. Answers to drawing the KAL subject

Based on the results of the interviews conducted, the subject of KAL is able to meet the indicators of mathematical communication skills of drawing and can explain problems into the form of images correctly and accurately and is able to explain the length, width, and height of the drawings he has made. An excerpt from the interview with the NDC subject is presented as follows:

Researcher: Explain the picture that you have made.

KAL : You draw it, the length is 24, now the width is 9, cut into a square, for example, the square is $x$, the right and left square is 2, so 24-2x is the length, now the width is the same, it makes 9-2x, keep making the height earlier was the $\mathrm{x}$.

It is clearly Figure 6 shows that the results of the written work of the KAL subject on the indicators of mathematical communication writing skills. KAL subject can use mathematical language correctly, and is able to explain ideas or situations from images that have been previously made in their own words in written form but are still incomplete. The KAL subject takes the cut side of the square with the symbol " $x$ ". However, the KAL subject did not specify the interval of " $x$ ".

\section{misal sisî porspoi wanos dipotona odalah $x$}

Figure 6. Answers to writing the KAL subject

Based on the results of the interviews conducted, the KAL subject was able to meet the indicators of writing mathematical communication skills and was able to explain ideas or situations from images that had been previously made but were still incomplete, because the KAL subject only explained for example the cut side of the square, namely $\mathrm{x}$, but had not explained the interval from $x$ itself. An excerpt from the interview with the NDC subject is presented as follows: 
Researcher : Explain the picture that you have made.

KAL : You draw it, the length is 24, now the width is 9, cut it into a square, let's say that a square is $x$.

It is clearly Figure 7 shows that the results of the written work of the KAL subject on the indicators of mathematical communication expression skills. The subject of KAL can clearly state mathematical solutions in writing, can use mathematical symbols, and perform calculations but is still incomplete. The subject is able to determine the length of the shape he made previously with the values $24-2 \mathrm{x}$, and for the width 9-2x, and the height a. Then the KAL subject is able to write the volume formula used with $\mathrm{V}=$ p.l.t and its calculations, the subject is also able to apply the first derivative with $V^{\prime}=0$, but the KAL subject cannot determine the maximum volume of the given problem.

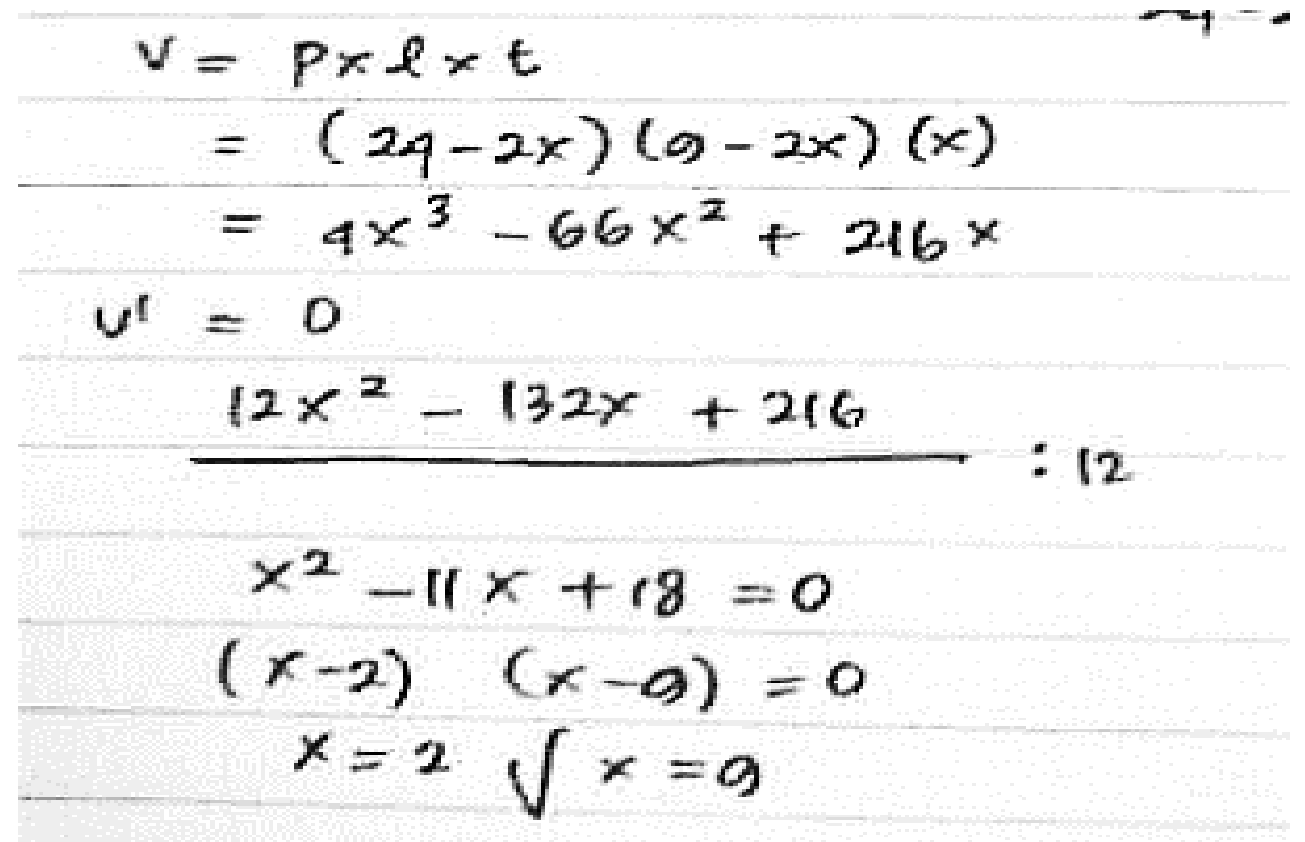

Figure 7. Answers to mathematical expression the KAL subject

Based on the results of the interviews conducted, the KAL subject is able to meet the indicators of mathematical expression communication skills and can explain the solution, but the KAL subject cannot determine the maximum volume of the given problem, the subject has tried to calculate the maximum volume but the result is negative, this is because the subject did not previously specify the $\mathrm{x}$ interval. An excerpt from the interview with the NDC subject is presented as follows:

Researcher : After you draw, what steps do you take?

KAL : Finding the volume.

Researcher : How?

KAL : Use that formula, it means that the length times the width times the height, put in $(24-2 x)(9-2 x)(x)$. Now the result is $4 x^{3}-66 x^{2}+216 x$, now it's lowered.

Researcher : Continue

KAL : The result means $12 x^{2}-132 x+216$.

Researcher : Then what is the next step?

KAL : That can be simplified, so it's $x^{2}-11 x+18$.

Researcher : Continue 
KAL $\quad$ So, you get $x=2$ or $x=9$.

Researcher : Then after that?

KAL : So, I just got there, sis.

Researcher : Why is the deck just that way?

KAL : The problem was that I tried to enter it, but the results were both negative.

Researcher : That means what you are doing only up to here?

KAL $\quad:$ Yes, Miss. It means that the maximum volume has not been obtained. It hasn't reached the final result value.

\subsubsection{Subject}

The subject of MM did not fulfill the mathematical communication indicators of drawing in solving the problem. Subject did not present the data or information from the question in the form of an image. MM subject could not write an explanation of the answer to the problem mathematically and did not use mathematical language or symbols appropriately and correctly. Figure 8 showed that MM subject is less able to express mathematical solutions in writing, and perform calculations but is wrong, because the MM subject solves the problem not with the volume block formula but by using the rectangular formula and the determination of the length and width values is still wrong.

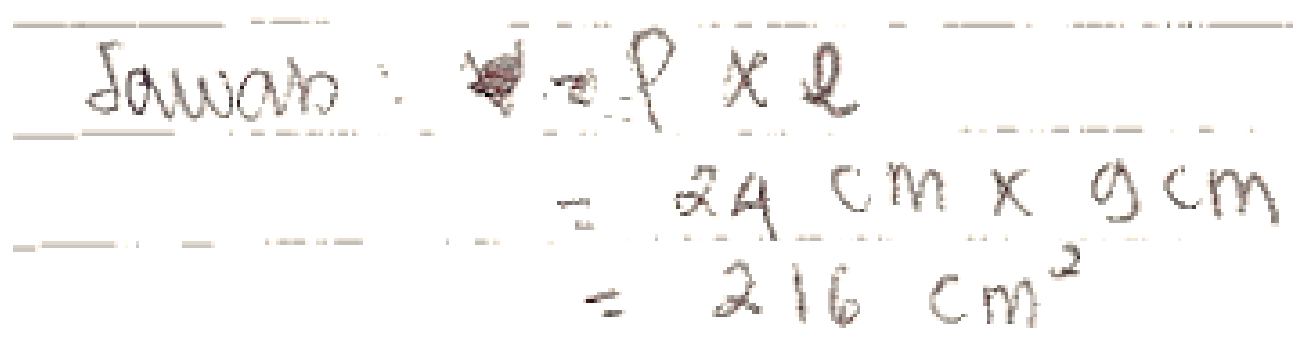

Figure 8. Answers to mathematical expression the MM subject

Based on the results of the interviews conducted, the MM subject is not able to meet the indicators of mathematical communication skills in mathematical expression and the MM subject explains mathematical solutions according to the answer sheet but the answer is still wrong, the MM subject is also still hesitant in answering what shapes roughly correspond to the problem in question. An excerpt from the interview with the NDC subject is presented as follows:

Researcher : What is the next step after you know what was being asked?

MM : I multiplied the length times the width.

Researcher : What do you think it is up to?

MM : Square

Researcher : Square? Square or shape?

MM : Square ... rectangle.

Researcher : Then you count the volume of the rectangle how it is?

MM : Length by width. The maximum volume is $216 \mathrm{~cm} 2$.

Data were also collected through in-depth interviews with the subjects of climbers (NDC), campers (KAL), and quitters (MM). Written test results data were compared with interview data to obtain valid data. From the research results written tests and interviews conducted by climbers subjects met all indicators of mathematical communication skills used, campers subjects tended to be able to meet all indicators of mathematical 
communication skills used, while quitters subjects were unable to meet all indicators of mathematical communication skills used.

\subsection{Discussion}

From the results of the tests and interviews, the researcher observed that the data obtained was sufficient, so the written test and interview were not continued to the next stage. From the analysis of written tests and interviews of mathematical communication skills, the following results are obtained:

\subsubsection{Mathematics prospective teacher with AQ climbers}

Based on the results of the description and analysis of the written test results, the prospective teacher with the AQ climbers category can meet all indicators of mathematical communication skills used by the researcher, including drawing, writing, and mathematical expression. Prospective teacher with AQ climbers are able to express and describe mathematical ideas in the form of pictures, AQ climbers are able to provide answers using their own language or problems using writing and algebra, and are able to explain ideas or situations from an image or graph with own words in written form. Prospective teacher with AQ climbers is able to state a situation in the form of a mathematical model, and is able to perform mathematical calculations correctly.

This is in line with Nartani, Hidayat, and Sumiyati (2015) improving the communication skills of mathematics indicated by students are able to express ideas or ideas with mathematics verbally sentence, students are actively involved in discussions about math, students can formulate definitions and generalizations about the math, students can formulate a definition of mathematics by using its own words. Mathematical communication skills are shown by students being able to express ideas or ideas with mathematical sentences verbally, students are actively involved in discussions about mathematics, students can formulate definitions and generalizations about mathematics, students can formulate mathematical definitions using their own words. This is also in line with Ansari (2012) who states that drawing communication skills are reflecting real objects, drawings and diagrams into mathematical ideas, writing is stating and explaining a mathematical drawing or model into a mathematical idea form, mathematical expression is express a situation or mathematical idea into a symbol or mathematical model and solve it. It can be concluded that the prospective teacher AQ climbers is able to meet all indicators of mathematical communication skills of drawing, writing, and mathematical expression. Stoltz (2000) states that the subject of climbers is a group of people who always try to reach the peak of success, are ready to face any obstacles, and always raise themselves to success.

This research is in line with the research of Paramita (2017), Kartika and Yazidah (2019), and Yuniarti (2015). In Paramita's research (2017) which states that the climbers subject is able to meet all indicators of mathematical communication skills including the ability to state a situation in mathematical language, the ability to describe mathematical ideas visually, the ability to explain mathematical ideas in writing, and the ability to evaluate mathematical ideas in writing. In Kartika and Yazidah's research (2019), which states that climbers students are more able to compile direct evidence than quitters and campers students. In research Yuniarti (2015) also states that the climber category is capable of almost all indicators of mathematical communication. 


\subsubsection{Mathematics prospective teacher with $A Q$ campers}

Based on the results of descriptions and analysis of written test results, prospective teacher with the AQ campers category tend to be able to meet all indicators of mathematical communication skills used by researchers, including drawing. writing, and mathematical expression. Prospective teacher with AQ campers are able to state, express and describe mathematical ideas in the form of images. AQ campers tend to be able to provide answers in their own language or problems using writing and algebra, and are able to explain ideas or situations from an image or graphic In their own words in written form. Prospective teacher with AQ campers tend to be able to state a situation in the form of a mathematical model, but have not been able to complete it completely in finding the maximum volume value requested in the problem. This is in line with Nartani, Hidayat, and Sumiyati (2015) improving the communication skills of mathematics indicated by students are able to express ideas or ideas with mathematics verbally sentence, students are actively involved in discussions about math, students can formulate definitions and generalizations about the math, students can formulate a definition of mathematics by using its own words. This is also in line with Ansari (2012) who states that drawing communication skills are reflecting real objects, drawings and diagrams into mathematical ideas, writing is stating and explaining a mathematical drawing or model into a mathematical idea form, mathematical expression is express a situation or mathematical idea into a symbol or mathematical model and solve it.

It can be concluded that the AQ campers tends to be able to meet all indicators of mathematical communication skills of drawing, writing, and mathematical expression. Stoltz (2000) stated that campers are a group of people who still have the desire to respond to existing challenges, but do not reach the peak of success and easily give up on what has been achieved. Stoltz (2000) also adds that campers do not fully exploit their potential, campers have a limited ability to change, especially major changes, campers live with the belief that after several years or after making a number of efforts, life should be relatively free of difficulties.

In this study, new things were found because the subject of AQ campers tended to meet all indicators of mathematical communication skills of drawing, writing, and mathematical expression. This is not in line with previous research conducted by Paramita (2017) and Yuniati (2015). In Paramita's (2017) research which states that campers tend to be able to fulfill two indicators, namely the ability to express a situation in mathematical language and the ability to visualize mathematical ideas only. Yuniarti's (2015) study which states that the camper category is quite capable in several communication indicators. Mathematically and the category of campers make process errors and conclusion errors.

\subsubsection{Mathematics prospective teacher with AQ quitters}

Based on the results of descriptions and analysis of written test results, the prospective teacher with the AQ quitters category cannot meet all indicators of mathematical communication skills used by researchers, including drawing. writing, and mathematical expression. AQ quitters is not able to meet all indicators of mathematical communication skills of drawing, writing, and mathematical expression. Stoltz (2000) states that quitters are a group of people who prefer to avoid and reject opportunities, easily give up, give up easily, tend to be passive, and are not enthusiastic about reaching the peak of success. Stoltz (2000) also adds that quitters have limited abilities in facing adversity, quitters tend to resist change and claim its every success, or to avoid it and actively walk away from it. The subject of quitters tends to think that the difficulties that arise will continue to occur, so that they are 
constantly overshadowed by obstacles that often arise, every difficulty, the cause is also considered something that will continue to appear again in the future (Hidayat \& Husnussalam, 2019; Hidayat, Noto, \& Sariningsih, 2019; Hidayat, Wahyudin, \& Prabawanto, 2018). It is proven in this study that the quitters subject is not able to meet all the indicators requested by the researcher.

This study is in line with the research of Paramita (2017), and Yuniarti (2015). In Paramita's research (2017) which states that quitters are not able to fulfill all indicators of mathematical communication skills, including the ability to express a situation in mathematical language, the ability to visualize mathematical ideas, the ability to explain mathematical ideas in writing, and the ability to evaluate mathematical ideas in writing. Yuniarti's research (2015) also states that the quitter category has not been able to meet almost every mathematical communication indicator and almost all types of errors occur in the quitters category. This is consistent with the results of this study where the quitters subject is not able to meet all indicators of mathematical communication skills including drawing, writing, and mathematical expression.

The results of this study finally produce a summary of the understanding of mathematical communication skills of prospective mathematics teachers in terms of AQ, as shown in the following Table 1.

Table 1. Summary of mathematical communication skills

\begin{tabular}{|c|c|c|c|c|c|}
\hline \multirow[b]{2}{*}{ No } & \multirow[b]{2}{*}{ Aspect } & \multirow[b]{2}{*}{ Indicator } & \multicolumn{3}{|c|}{ Category } \\
\hline & & & $\begin{array}{c}\text { AQ } \\
\text { Climbers }\end{array}$ & $\begin{array}{c}\text { AQ } \\
\text { Campers }\end{array}$ & $\begin{array}{c}\text { AQ } \\
\text { Quitters }\end{array}$ \\
\hline 1. & Drawing & $\begin{array}{l}\text { The ability to express, } \\
\text { express and describe } \\
\text { mathematical ideas in the } \\
\text { form of pictures, graphs or } \\
\text { visual mathematical models. }\end{array}$ & Fulfilled & Fulfilled & $\begin{array}{c}\text { Not } \\
\text { Fulfilled }\end{array}$ \\
\hline 2. & Writing & $\begin{array}{l}\text { The ability to provide } \\
\text { answers using your own } \\
\text { language or problems using } \\
\text { writing and algebra, and to } \\
\text { explain an idea or situation } \\
\text { from a picture or graphic in } \\
\text { your own words in written } \\
\text { form. }\end{array}$ & Fulfilled & Fulfilled & $\begin{array}{c}\text { Not } \\
\text { Fulfilled }\end{array}$ \\
\hline 3. & $\begin{array}{l}\text { Mathematical } \\
\text { Expression }\end{array}$ & $\begin{array}{l}\text { The ability to express } \\
\text { mathematical concepts by } \\
\text { expressing everyday events } \\
\text { in mathematical language or } \\
\text { symbols, and expressing a } \\
\text { situation in the form of a } \\
\text { mathematical model }\end{array}$ & Fulfilled & $\begin{array}{l}\text { Almost } \\
\text { Fulfilled }\end{array}$ & $\begin{array}{c}\text { Not } \\
\text { Fulfilled }\end{array}$ \\
\hline
\end{tabular}

Table 1 shows that the results of the study show that the subjects of prospective mathematics teachers who have AQ climbers and AQ campers are able to meet all indicators of mathematical communication skills, indicators of mathematical communication skills used include drawing, writing, and mathematical expression, while the subject of mathematics prospective teacher. Those who have AQ quitters are not able to meet all indicators of mathematical communication ability. The indicators of mathematical 
communication abilities used include drawing, writing, and mathematical expression. The results of each individual in communicating the problems obtained are in accordance with their AQ. This is in line with Syarifah, Sujatmiko, and Setiawan (2017), mathematical communication is the process of expressing mathematical ideas and understanding verbally, visually, and in writing, using numbers, symbols, pictures, graphs, diagrams, and words. someone. The results of this study are also in line with Nopiyani, Turmudi, and Prabawanto (2016), mathematical communication is the ability to express mathematical ideas or ideas either in writing or in pictures. This is also in line with Murtafiah (2016) that mathematical communication is the ability to express mathematical ideas through speech, writing, demonstrations, and visually depicting them in different types for each person.

\section{CONCLUSION}

Based on the results of research and discussion that has been done with the subject of climbers, the conclusion is that students are able to solve problems using mathematical communication properly and correctly. The three indicators of communication the subject is able to meet all the indicators of mathematical communication used. The subject of campers is quite capable of solving mathematical communication problems properly and correctly, but there are calculations in resolving incomplete problems. The three indicators of communication the subject tends to be able to meet all the indicators of mathematical communication used. The subject of quitters has not been able to solve problems using mathematical communication properly. The three stages of communication, the subject tends not to be able to meet all the indicators of mathematical communication used. Based on the results and conclusions of this study, the following suggestions can be made: to examine more deeply about mathematical communication with the factors that influence students. In addition, it is also based on conducting further research using other types of data based on the findings in this study.

\section{REFERENCES}

Ansari, B. I. (2012). Komunikasi matematik dan politik. Banda Aceh: Yayasan Pena.

Fridanianti, A., Purwati, H., \& Murtianto, Y. H. (2018). Analisis kemampuan berpikir kritis dalam menyelesaikan soal aljabar kelas VII SMP N 2 Pangkah ditinjau dari gaya kognitif reflektif dan kognitif impulsif. Aksioma: Jurnal Matematika dan Pendidikan Matematika, 9(1), 11-20. https://doi.org/10.26877/aks.v9i1.2221

Hampson, M., Patton, A., \& Shanks, L. (2011). Ten ideas for 21st century education. London: Innovation Unit.

Hapsari, V. S., Nizaruddin, N., \& Muhtarom, M. (2019). Kemampuan Representasi Matematis Siswa SMP pada Mata Pelajaran Bangun Ruang Sisi Datar. Imajiner: Jurnal Matematika dan Pendidikan Matematika, 1(6), 267-278. https://doi.org/10.26877/imajiner.v1i6.4853

Hidayat, W., Herdiman, I., Aripin, U., Yuliani, A., \& Maya, R. (2018). Adversity quotient (AQ) dan penalaran kreatif matematis mahasiswa calon guru. Jurnal Elemen, 4(2), 230-242.

Hidayat, W., \& Husnussalam, H. (2019). The adversity quotient and mathematical understanding ability of pre-service mathematics teacher. Journal of Physics: Conference Series, 1315(1), 012025. https://doi.org/10.1088/17426596/1315/1/012025 
Hidayat, W., Noto, M. S., \& Sariningsih, R. (2019). The influence of adversity quotient on students' mathematical understanding ability. Journal of Physics: Conference Series, 1157(3), 032077. https://doi.org/10.1088/1742-6596/1157/3/032077

Hidayat, W., Wahyudin, W., \& Prabawanto, S. (2018). The Mathematical Argumentation Ability and Adversity Quotient (AQ) of Pre-Service Mathematics Teacher. Journal on Mathematics Education, 9(2), 239-248. https://doi.org/10.22342/jme.9.2.5385.239-248

Kartika, E. D., \& Yazidah, N. I. (2019). analisis kemampuan pembuktian matematis pada matakuliah analisis real berdasarkan adversity quotient. Prima: Jurnal Pendidikan Matematika, 3(2), 152-157. https://doi.org/10.31000/prima.v3i2.1385

Murtafiah, W. (2016). Kemampuan komunikasi matematika mahasiswa calon guru matematika dalam menyelesaikan masalah persamaan diferensial ditinjau dari gender. Jurnal Math Educator Nusantara: Wahana Publikasi Karya Tulis Ilmiah Di Bidang Pendidikan Matematika, 2(1), 31-41.

Nartani, C. I., Hidayat, R. A., \& Sumiyati, Y. (2015). Communication in mathematics contextual. International Journal of Innovation and Research in Educational Sciences, 2(4), 284-287.

Nopiyani, D., Turmudi, T., \& Prabawanto, S. (2016). Penerapan pembelajaran matematika realistik berbantuan geogebra untuk meningkatkan kemampuan komunikasi matematis siswa SMP. Mosharafa: Jurnal Pendidikan Matematika, 5(2), 45-52. https://doi.org/10.31980/mosharafa.v5i2.259

Nugrahanto, S., \& Zuchdi, D. (2019). Indonesia PISA Result and Impact on The Reading Learning Program in Indonesia. International Conference on Interdisciplinary Language, Literature and Education (ICILLE 2018), 373-377. https://doi.org/10.2991/icille-18.2019.77

Paradesa, R., \& Ningsih, Y. L. (2017). Pembelajaran matematika berbantuan Maple pada mata kuliah kalkulus integral terhadap kemampuan komunikasi matematis mahasiswa. Jurnal Pendidikan Matematika RAFA,3(1), 70-81. https://doi.org/10.19109/jpmrafa.v3i1.1442

Paramita, L. W. (2017). Kemampuan komunikasi matematis ditinjau dari adversity quotient melalui penerapan model pembelajaran SSCS pada siswa kelas VIII (Doctoral dissertation). Semarang: Universitas Negeri Semarang.

Salam, R. (2017). Efektivitas penggunaan model pembelajaran kooperatif tipe think pair share (tps) untuk meningkatkan kepercayaan diri dan komunikasi matematis. Indonesian Journal of Educational Studies, 20(2), 108-116.

Scott, C. L. (2015). The futures of learning 3: What kind of pedagogies for the 21st century?. ERF Working Papers Series, No. 15. Paris: UNESCO Education Research and Foresight.

Soh, T. M. T., Arsad, N. M., \& Osman, K. (2010). The relationship of 21st century skills on students' attitude and perception towards physics. Procedia-Social and Behavioral Sciences, 7, 546-554. https://doi.org/10.1016/j.sbspro.2010.10.073

Son, A. L. (2015). Pentingnya Kemampuan Komunikasi Matematika Bagi Mahasiswa Calon Guru Matematika. Gema Wiralodra, 7(1), 1-8.

Stoltz, G. P. (2000). Adversity quotient: Mengubah hambatan menjadi peluang. Jakarta: PT 
Grasindo.

Sugiyono. (2008). Metode penelitian pendidikan:(pendekatan kuantitatif, kualitatif dan $R \&$ $D)$. Bandung: Alfabeta.

Syarifah, T. J., Sujatmiko, P., \& Setiawan, R. (2017). Analisis Kemampuan Komunikasi Matematis Tertulis Ditinjau dari Gaya Belajar pada Siswa Kelas XI MIPA 1 SMA Batik 1 Surakarta Tahun Pelajaran 2015/2016. Jurnal Pendidikan Matematika dan Matematika (JPMM) Solusi, 1(2), 1-19.

Ulfa, K., Buchori, A., \& Murtianto, Y. H. (2017). Efektivitas Model Guided Discovery Learning untuk Video Pembelajaran dalam Mengetahui Perbedaan Kemampuan Pemecahan Masalah Matematika Siswa. MUST: Journal of Mathematics Education, Science and Technology, 2(2), 267-275. https://doi.org/10.30651/must.v2i2.888

Wijaya, E. Y., Sudjimat, D. A., \& Nyoto, A. (2016). Transformasi pendidikan abad 21 sebagai tuntutan pengembangan sumber daya manusia di era global. Prosiding Seminar Nasional Pendidikan Matematika, 1, 263-278.

Yuniarti, D. A. F. (2015). Analisis hasil penilaian diagnostik kemampuan komunikasi matematis dalam pembelajaran osborn berdasarkan adversity quotient(Tesis). Semarang: Universitas Negeri Semarang. 